\title{
Pemberdayaan Masyarakat Desa dalam Pengelolaan Sampah Rumah Tangga Melalui Media Youtube (Studi Kasus: Kampung Bengle, Desa Bojong Jengkol, Kecamatan Ciampea, Kabupaten Bogor, Provinsi Jawa Barat)
}

\author{
Prima Yustitia Nurul Islami*1, Suyuti² \\ 1,2Jurusan Pendidikan Sosiologi, Fakultas Ilmu Sosial, Universitas Negeri Jakarta, Indonesia \\ *e-mail: primayustitia@unj.ac.id ${ }^{1}$ yuti@unj.ac.id $^{2}$
}

\begin{abstract}
Abstrak
Pengelolaan sampah saat ini memiliki persoalan besar terutama persoalan penumpukan sampah di tempat pembuangan sampah akhir. Salah satu penyebab persoalan tersebut adalah tidak terbiasanya masyarakat untuk melakukan pengelolaan sampah rumah tangga melalui sistem pilah sampah sejak dari rumah tangga. Pemberdayaan masyarakat dalam pengelolaan sampah menjadi proses penting untuk mengurangi penumpukan sampah pada lokasi pembuangan akhir dan menjadi peluang untuk meningkatkan pendapatan masyarakat. Keberadaan media youtube dapat menjadi sarana untuk meningkatkan kesadaran masyarakat tentang proses pemilahan sampah mulai dari rumah tangga dan mengurangi potensi penumpukkan sampah di tempat pembuangan sampah akhir. Pengabdian masyarakat ini dilakukan dengan pendekatan blended yang menggabungkan antara kegiatan ceramah secara langsung dengan ceramah menggunakan media youtube. Hasil kegiatan secara umum berjalan lancar dan berhasil yang diukur dari peningkatan pengetahuan tentang pengelolaan sampah, model pengeloalan sampah dan informasi tentang bank sampah sebelum dan setelah kegiatan dilaksanakan.
\end{abstract}

Kata kunci: Lingkungan, Pemberdayaan Masyarakat, Pengelolaan Sampah

\begin{abstract}
Waste management are currently a big problems because of accumulation waste in final disposal site. The caused of waste problems are the people in community not to accustomed household waste management start from sorting the waste. Commmunity empowerment in waste management is an important process to reduce the accumulation of waste at final disposal sites. In the other ways, waste management have an opportunity to increace communitie's income. Youtube can be a media too increase community awarnees especially about waste and sorting waste start from household to reduce potential accumulation waste at final disposal site. This community service was carried out with blended approach that combines direct meeting and discussion and using Youtube media to share the information about waste management. General result of all activities run cleary and successgully as measured by increasing knowledge and models of waste management and also about waste bank before and after the activity is carried out.
\end{abstract}

Keywords: Community Development, Environment, Waste Management

\section{PENDAHULUAN}

Persoalan lingkungan hidup memiliki dimensi yang sangat luas namun berdampak sangat erat dengan kehidupan masyarakat sehari hari. Salah satu persoalan lingkungan yang sangat dekat dengan kehidupan sehari hari adalah persoalan sampah. Sampah didefinisikan sebagai bahan buangan dari berbagai kegiatan rumah tangga, komersial, industri maupun berbagai aktivitas lainnya yang umumnya dilakukan oleh manusia (Rainiyati et al., 2019). Berdasarkan definisi tersebut dapat dipahami bahwa sampah memiliki keterkaitan baik secara langsung maupun tidak langsung bagi kelangsungan lingkungan hidup.

Indonesia merupakan negara yang memiliki jumlah penduduk terbanyak keempat di dunia yaitu mencapai 264 juta jiwa. Hal tersebut berdampak pada jumlah sampah yang dihasilkan di Indonesia. Berdasarkan data capaian kinerja pengelolaan sampah di Indonesia menunjuukan bahwa timbunan sampah dari 231 Kabupaten/Kota di Indonesia mencapai 26 juta ton per tahun, sebanyak $22,74 \%$ sudah dilakukan pengurangan sampah, sebanyak $52,61 \%$ sudah terdapat proses penanganan sampah dan jika dilihat berdasarkan pengeloaan sampah sebanyak $75,25 \%$ sampah sudah dikelola dengan baik dan sebanyak 24,65\% sampah belum dikelola dengan baik. 
Pengelolaan sampah pada dasarnya merupakan suatu kegiatan yang sistematis, menyeluruh, dan berkesinambungan diatur melalui UU No.18 tahun 2008 tentang pengelolaan sampah. Aturan tentang pengelolaan sampah menjelaskan bahwa pengelolaan sampah pada dasarnya merupakan tanggung jawab personal untuk dapat mengelola sampah yang dihasilkan namun terdapat sistem yang membantu proses pengumpulan sampai pada tahap pembuangan sampah ke tempat pembuangan akhir (TPA). Model pengelolaan sampah dengan sistem kumpulbuang-angkut menjadi model yang masih digunakan saat ini. Hal tersebut berdampak pada persoalan yang muncul di lokasi pembuangan akhir.

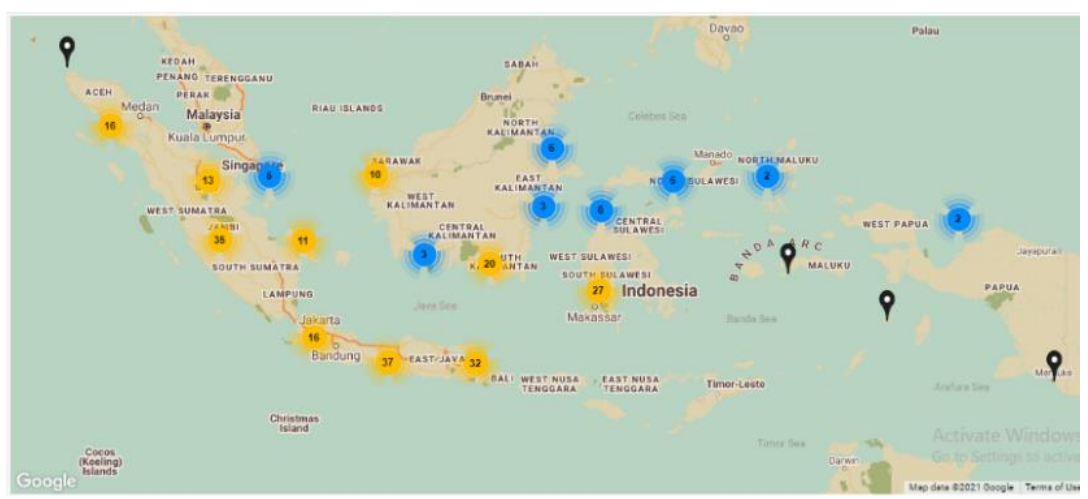

Gambar 1. Data lokasi Tempat Pembuangan Sampah Akhir (TPA) di Indonesia (sumber: http://sipsn.menlhk.go.id/sipsn/public/home/peta)

Sampah rumah tangga merupakan salah satu persoalan yang mengancam keberlanjutan lingkungan hidup saat ini. Peningkatan jumlah penduduk beriringan dengan bertambahnya volume sampah yang dihasilkan dari rumah tangga. Hal tersebut menyebabkan berbagai persoalan dimulai dari sampah itu sendiri, pola pengelolaan sampah hingga lokasi pembuangan sampah akhir. Persoalan pengelolaan sampah rumah tangga tidak hanya terjadi di perkotaan. Pada masyarakat desa pola pengelolaan sampah umumnya berbeda dengan masyarakat yang tinggal di perumahan maupun perkotaan. Sistem kelola sampah di perkotaan maupun perumahan, pada umumnya adalah berbasis tempat pembuangan akhir (dikumpulkan kemudian di angkut (Utami et al., 2008). Masyarakat pedesaan umumnya membuang sampah pada lokasi tertentu seperti sungai (Listiyandini et al., 2018), tebing/jurang, dan lahan kosong di sekitar kawasan pemukiman warga.

Pengelolaan sampah rumah tangga menjadi persoalan yang penting seiring dengan bertambahnya jumlah penduduk di suatu wilayah. Pulau Jawa merupakan wilayah yang menghasilkan sampah terbesar di Indonesia yaitu mencapai 21,2 ton per tahun (KLHK, 2008). Besarnya potensi sampah yang dihasilkan memiliki dampak siginfikan pada persoalan lingkungan berupa pencemaran atau persoalan daya dukung lingkungan itu sendiri. Sampah merupakan salah satu maslaah utama yang menyebabkan pencemaran lingkungan, antara lain pencemaran air akibat zat berbahaya, pencemaran udara akibat bau tidak sedap, sumber penyakit dan sumber bencana alam seperti banjir (Mujiburrahmad \& Firmansyah, 2014). Hal tersebut menyebabkan persoalan pengelolaan sampah rumah tangga menjadi satu hal yang penting untuk dilaksanakan oleh masyarakat.

Berdasarkan data yang diperolah dari Dinas Perumahaan dan Pemukiman (Distarkim) Provinsi Jawa Barat pada tahun 2010, Kabupaten Bogor adalah penghasilkan sampah terbanyak jika dibandingkan dengan kabupaten lain di Jawa Barat sebesar 134.774,80 liter per hari. Hal tersebut diperkuat dengan data dari Dinas Pekerjaan Umum yang menjelaskan bahwa pada tahun 2020 jumlah timbunan sampah per orang per hari di Kabupaten Bogor mencapai 2 liter (Gambar 1). Hal tersebut menunjukkan dalam satu hari sampah yang dihasilkan di Kabupaten Bogor mencapai 6 juta liter per harinya dengan komposisi jumlah timbunan sampah di pedesaan mencapai 8000 liter per harinya. 


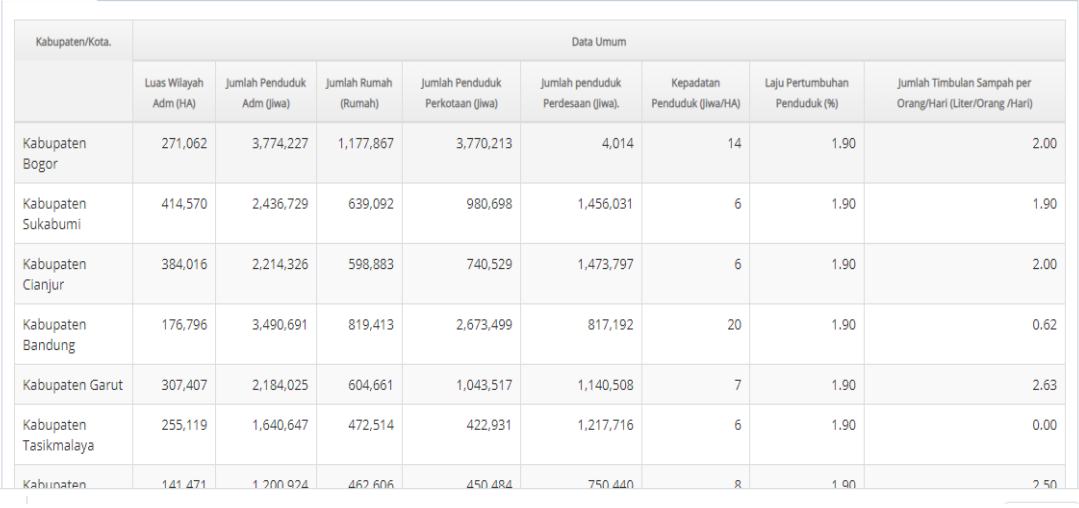

Gambar 2. Jumlah Sampah Di Kabupaten Bogor

(sumber:http://ciptakarya.pu.go.id/plp/simpersampahan/baseline/rosampahdataproplist.php? $\underline{\mathrm{id}=3200 \& \text { tabid=dataumum) }}$

Potensi penumpukan sampah pada lokasi pembuangan sampah akhir bukanlah keniscayaan, namun pasti akan terjadi dengan banyak efek domino kerusakan lingkungan didalamnya. Hal tersebut tidak akan jauh berbeda terjadi pada masyarakat pedesaan, akibat peningkatkan jumlah penduduk, persoalan alih fungsi lahan sawah dan persoalan pengelolaan sampah yang tidak baik. Jika hal tersebut terus menerus dibiarkan makan timbunan sampah akan menjadi satu bencana yang tidak dapat dihindari dikemudian hari. Keberadaan sampah plastik memberikan dampak siginifikan bagi kerusakan lingkungan karena 20\% sampah yang dihasilkan akan berakhir di sungai maupun pantai dan sebagian besar adalah sampah plastik yang dapat terdegradasi dalam waktu puluhan hingga ratusan tahun.

Besarnya potensi kerusakan lingkungan akibat sampah tidak beriringan dengan kesadaran masyarakat terhadap pengelolaan sampah rumah tangga. Hal tersebut tercermin dalam tidak adanya data komprehensif yang menunjukkan jenis sampah yang dihasilkan setiap harinya (Gambar 2). Ketidakadaan data tersebut menunjukkan bahwa sampah rumah tangga tidak melalui proses pemilahan terlebih dahulu.

\begin{tabular}{|c|c|c|c|c|c|c|c|c|c|}
\hline \multirow[t]{2}{*}{ KabupatenKota } & \multicolumn{9}{|c|}{ Kemposisi Berat Sampah $(x)$} \\
\hline & Organik & Kertas & Kaca & Plastik & Logam & Kayu & Kain & Karet & Lain-tain \\
\hline Kabupaten Bogor & 0 & 0 & 0 & 0 & 0 & 0 & 0 & 0 & 0 \\
\hline Kabupaten Sukabumi & 2 & 1 & 0 & 1 & 0 & 0 & 0 & 0 & 0 \\
\hline Kabupaten Cianjur & 61 & 9 & 1 & 8 & 1 & 1 & 2 & 1 & 16 \\
\hline Kabupaten Bandung & 51 & 8 & 4 & 0 & 0 & 0 & 11 & 0 & 21 \\
\hline Kabupaten Garut & 0 & 0 & 0 & 0 & 0 & 0 & 0 & 0 & 0 \\
\hline Kabupaten Tasikmalaya & 0 & 0 & 0 & 0 & 0 & 0 & 0 & 0 & 0 \\
\hline Kabupaten Ciamis & 66 & 4 & 2 & 5 & 2 & 1 & 0 & 0 & 0 \\
\hline
\end{tabular}

Gambar 3. Komposisi Berat Sampah Per Jenisnya

(sumber:http://ciptakarya.pu.go.id/plp/simpersampahan/baseline/rosampahdataproplist.php? $\underline{\mathrm{id}=3200 \& \text { tabid=dataumum) }}$

Kondisi tersebut menunjukkan bahwa persoalan pengelolaan sampah rumah tangga belumlah dilakukan secara optimal baik oleh pemerintah daerah yang bekerjasama dengan dinas pekerjaan umum maupun oleh pemerintah desa dalam meningkatkan kesadaran dan pemahaman masyarakat terkait dengan sistem pengelolaan sampah rumah tangga yang baik. Pada dasarnya timbunan sampah padat tidak dapat dikurangi namun dapat dikelola dengan lebih baik. Undang undang nomor 18 tahun 2008 tentang pengelolaan sampah menjelaskan bahwa pengelolaan sampah merupakan kegaitan sistematis, menyeluruh, dan berkesinambungan yang meliputi pengurangan dan penanganan sampah. Penjelasan lain dalam undang undang tersebut adalah 
bahwa setiap orang dalam pengelolaan sampah rumah tangga wajib menangani sampah dengan cara yang berwawasan lingkungan.

Hal tersebut menjadi pendorong untuk melakukan kegiatan pengabdian kepada masyarakat dalam bentuk pemberdayana masyarakat untuk dapat mengelola sampah rumah tangga berbasis komunitas. Persoalan sampah di pedesaan sebagaimana yang telah dijelaskan sebelumnya bukanlah persoalan penting yang dirasakan oleh masyarakat pada saat ini. Hal tersebut disebabkan masyarakat memiliki pola sendiri dalam mengelola sampah dengan membuat ke sungai, membuat pada lokasi pembuangan setempat, membakar, maupu mengubur sampah tersebut. Namun, persoalan pengeloalan sampah yang tidak baik akan berdampak pada munculnya persoalan di masa yang akan datang salah satunya adalah persoalan pencemaran lingkungan (udara, air, tanah).

Desa Bojong Jengkol, secara administratif berbatasan dengan Desa Benteng di sebelah utara, Desa Cinangka di sebelah selatan, desa Cihideung Udik di sebelah timur dan Desa Tegal Waru di sebelah barat. Kampung Bengle merupakan salah satu kampung yang berada di Desa Bojong Jengkol. Kampung Bengle terdiri dari 200 Kepala Keluarga dengan mata pencaharian utama adalah sektor informal dan petani. Lokasi Kampung Bengle berada $\pm 65 \mathrm{Km}$ dari Jakarta tepatnya dari Universitas Negeri Jakarta Kampus A Rawamangun Muka. Dilihat dari ketersediaan infrastuktur untuk menunjang kegiatan masyakat antara lain mesjid sebagai sarana ibadah, balai warga sebagai sarana diskusi warga kampung dan posyandu.

Secara umum masyarakat Kampung Bengle hanya \pm 50 persen warga masyarakat yang sudah memiliki sarana MCK dalam di dalam rumah, sedangakn sebagian besar masih menggunakan sarana MCK umum maupun menggunakan sungai untuk memenuhi kebutuhan air dan mandi. Selain itu tidak adanya tempat pembuangan sampah akhir di Kampung Bengle sehingga pembuangan sampah dilakukan oleh warga di tempat yang secara tidak langsung menjadi lokasi pembuangan sampah akhir seperti tebingan jurang, sungai, maupun berserakan disekitar rumah.

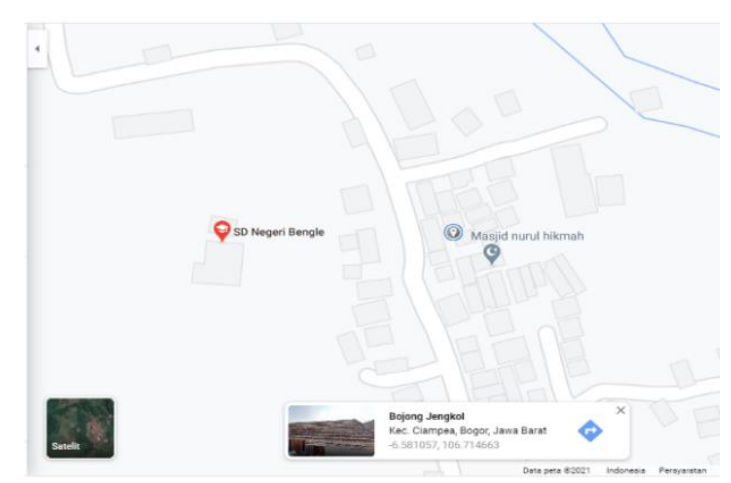

Gambar 4. Kampung Bengle, Desa Bojong Jengkol, Kecamatan Ciampea,Kabupaten Bogor (sumber: https://www.google.co.id/maps/search/kampung+bengle,+desa+bojong+jengkol/@$\underline{6.5806047,106.7133047,18 \mathrm{z})}$

Masyarakat Kampung Bengle belum memiliki sistem pengelolaan sampah rumah tangga secara terpadu. Umumnya masyarakat mengelola sampahnya dengan beberapa pola antara lain membuang sampah di kali/ sungai, membuang sampah pada lahan kosong atau tebingan jurang, membakar sampah, dan mengubur sampah disekitar kawasan tempat tinggal. Belum adanya sistem pengelolaan sampah secara baik akan memberikan dampak pada potensi kerusakan lingkungan di masa yang akan datang akibat peningkatan jumlah penduduk. Keberadaan sampah rumah tangga yang tidak dikelola dengan baik menyebabkan berbagai persoalan pada masyarakat seperti pencemaran sumber mata air, persoalan penyakit akibat terlalu banyak tumpukan sampah, polusi udara akibat bau yang tidak sedap dan berbagai dampak lainnya. Belum adanya sistem pengelolaan sampah rumah tangga pada masyarakat Kampung Bengle disebabkan oleh beberapa faktor antara lain belum adanya kesadaran masyarakat untuk melakukan pengelolaan sampah, tidak adanya pengetahuan masyarakat tentang bagaimana melakukan pengelolaan 
sampah dengan baik dan belum adanya sistem kelembagaan lokal yang membantu mengelola sampah rumah tangga masyarakat lebih terintegrasi dan berwawasan lingkungan.

Berbagai persoalan tersebut menjadi alasan utama perlunya pemberdayaan masyarakat dalam pengelolaan sampah rumah tangga di Kampung Bengkle. Masyarakat tidak akan memiliki kesadaran untuk melakukan pengelolaan sampah dengan baik sejak di rumah tangga jika mereka tidak memiliki pengetahuan terkait pentingnya pengelolaan sampah dan dampak apa saja yang dapat diterima jika sampah dapat dikelola dengan baik oleh masyarakat. Pengembangan sistem kelembangaan lokal dalam mengelola lingkungan desa terutama sebagai basis dalam mengelola sampah rumah tangga menjadi penting dalam program pengembangan masyarakat desa saat ini. Berdasarkan hal tersebut, kami selaku tim pengabdian masyarakat bersama dengan mitra dalam hal ini masyarakat Kampung Bengle berupaya untuk dapat meningkatkan kesadaran, pengetahuan dan kemampuan masyarakat untuk dapat menciptakan sistem tata kelola sampah rumah tangga berbasis komunitas yang sesuai dengan kebutuhan dan karakteristik masyarakat Kampung Bengle.

\section{METODE}

Pelaksanaan kegiatan pengabdian menggunakan pendekatan blended dengan menggabungkan antara kegiatan ceramah langsung dengan masyarakat dan ceramah menggunakan media youtube. Metode ini dipilih sebab adanya aturan dari pemerintah pusat dan pemerintah daerah yang diterapkan juga di desa untuk tidak melakukan pertemuan secara luring dengan mengumpulkan massa. Berdasarkan hal tersebut kegiatan ini dilakukan dengan luring terbatas dan menginformasikan secara daring dengan harapan informasi dapat disebarkan lebih luas. Kegiatan luring dilakukan melalui pertemuan dengan kepala desa dan sebagian aparat desa untuk memberikan booklet dan menginformasikan link youtube yang dapat diakses oleh masyarakat desa setempat. Booklet berisi materi yang dapat dibaca dan dilihat (karena lebih banyak menggunakan gambar) sedangkan link youtube berupa video yang berisikan materi yang diambil dari literarur dan penelitian mengenali model pengelolaan sampah rumah tangga dan pengelolaan sampah berbasis komunitas.

Pendekatan unjuk kerja dalam rangka implementasi model pengelolaan sampah rumah tangga bertujuan agar masyarakat memiliki gambaran secara utuh tidak hanya dalam bentuk teori namun praktik nyata bagaimana mengimplementasikannya dalam kehidupan sehari hari. Pemberdayaan masyarakat dengan menggunakan pendekatan penyuluhan (ceramah dan diskusi) diharapkan mampu meningkatkan pengetahuan masyarakat tentang pengelolaan sampah rumah tangga dan selanjutnya dapat meningkatkan kemampuan masyarakat untuk dapat mengelola sampah rumah tangga dengan lebih baik. Prosedur kerja yang dilakukan yaitu:

1. Melakukan observasi lapangan terlebih dahulu dan menjalin kerjasama dengan mitra dalam hal ini adalah Kepala Desa Bojong Jengkol dan Ketua RW Kampung Bengle;

2. Mengidentifikasi target pemberdayaan masyarakat yaitu perempuan perwakilan setiap keluarha yang akan terliabt sebagai peserta pelatihan;

3. Menentukan waktu dan lokasi pelaksanaan kegiatan pemberdayaan;

4. Membuat rencana dan gambaran kegiatan serta target capaian kegiatan pemberdayaan;

5. Membuat evaluasi hasil kegiatan pemberdayaan.

\section{HASIL DAN PEMBAHASAN}

Pelaksanaan kegiatan pengabdian kepada masyarakat melalui beberapa tahapan kegiatan yang bertujuan untuk memberikan dampak siginifikan terhadap peserta yang mengikuti kegiatan pemberdayaan masyarakat yang bertujuan untuk meningkatkan pemahamannya dalam melakukan pengelolaan sampah rumah tangga berbasis komunitas. Pendekatan pemberdayaan kali ini menggunakan metode blended learning disebabkan oleh beberapa hal antara lain : 1)adanya aturan pembatasan sosial sehingga kegiatan pemberdayaan tidak dapat dilakukan dengan melibatkan banyak orang; 2) penggunaan media youtube bertujuan agar informasi yang 
disampaikan dapat menjangkau khalayak yang lebih luas dan informasi dapat diterima secara berulang; 3) pemberian booklet bertujuan agar masyarakat memiliki panduan yang dapat digunakan sehari hari. Adapun rincian dari penjelasan mengenai capaian yang didapat beserta analisa berdasarkan beberapa tahapan pelaksanaan kegiatan adalah sebagai berikut:

\subsection{Capaian Hasil Tahap I}

Pada tahap I, terciptanya suatu persamaan visi dan misi diantara kelompok kerja atau tim serta kesiapan mental dalam menjalankan kegiatan melalui perencanaan yang matang dan sharing dalam internal tim serta melakukan berbagai langkah strategis yang tepat dalam melaksanakan kegiatan. Pada tahap I, tim berhasil untuk membuat materi dan perencanaan kegiatan sinergitas terkait dengan kebutuhan masyarakat terutama terkait dengan materi awal. Adapun materi pelatihan yang telah disiapkan adalah sebagai berikut:

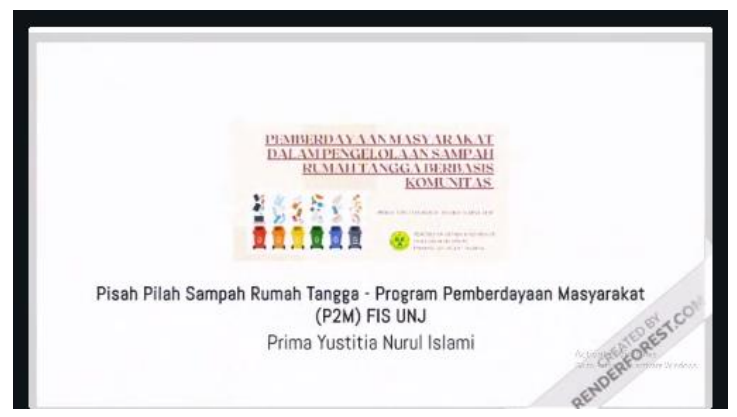

\section{PISAH PILAH SAMPAH RUMAH TANGGA}

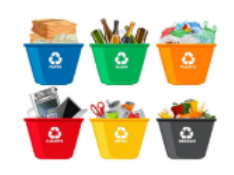

Gambar 5. Materi Pemberdayaan Pengelolaan Sampah Rumah Tangga

\subsection{Capaian Hasil Tahap II}

Pada tahap II, tim mulai melakukan komunikasi sekaligus penjelasan kepada pihak pemerintah desa dan aparat desa terkait materi pengelolaan sampah dan pentingnya bagi masyarakat. Penyampaian maksud dan tujuan juga sembari melakukan pemaparan tentang model pengelolaan sampah berbasis komunitas. Penjelasan materi tersebut dilakukan melalui paparan tentang pentingnya pengelolaan sampah dan bagaimana membuat model pengelolaan sampah berbasis komunitas.

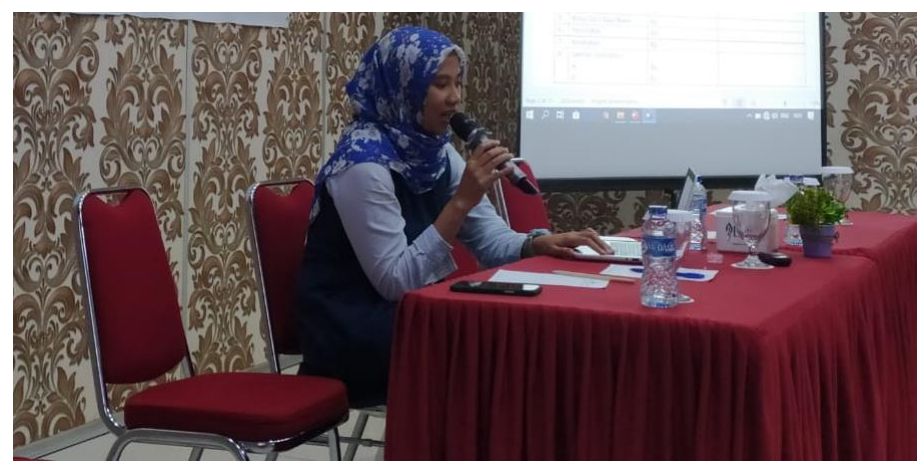

Gambar 6. Pemaparan materi kepada aparat pemerintah desa

\subsection{Capaian Hasil Tahap III}

Pada tahap III, pembuatan kesepakatan jadwal kegiatan pemberdayaan terbatas bersama perwakilan masyarakat yang akan dilakukan secara luring serta mengiformasikan link youtube yang dapat diakses oleh masyarakat yang tidak dapat hadir secara luring. Selain itu membuat beberapa persiapan terkait bahan presentasi, agenda, banner, dan booket. Adapun jadwal pelatihan dilakukakn pada tanggal 11 September 2021 dimulai pada pukul 08.00 WIB sampai 12.00 WIB. 


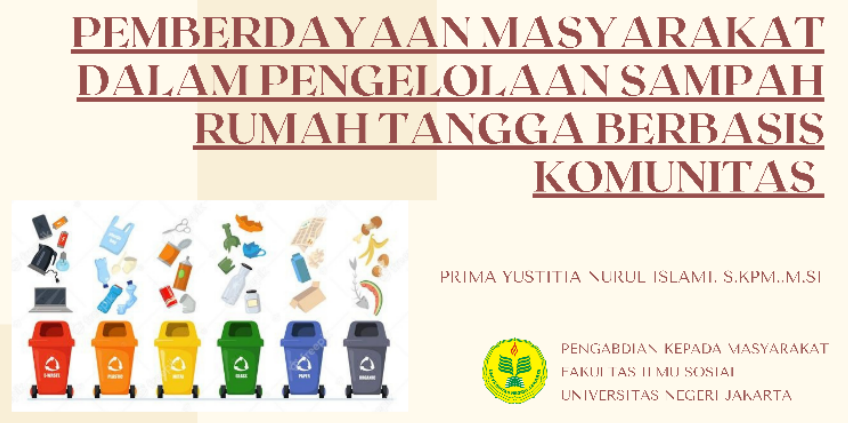

Gambar 7. Banner kegiatan pengabdian kepada masyarakat

\subsection{Capaian Hasil Tahap IV}

Pada tahap IV, terdapat beberapa capaian hasil kegiatan terkait dengan pelaksanaan kegiatan pemberdayaan pengelolaan sampah berbasis masyarakat antara lain:

1. Terlaksananya kegiatan pengabdian masyarakat pengolahan sampah rumah tangga berbasis komunitas sebagai bagian dari rangkaian kegiatan pengabdian kepada masyarakat yang dilakukan oleh Program Studi Pendidikan Sosiologi dan bekerjasama dengan masyarakat Kampung Bengle pada Sabtu, 11 September 2021 dengan metode luring.

2. Kegiatan ini juga disertai dengan pemberian booklet kepada masyarakat Kampung Bengle serta memberikan informasi terkait link zoom yang dapat diakses untuk mengetahui informasi terkait pengelolaan sampah rumah tangga.

3. Kegiatan ini menghasilkan beberapa masukan untuk meningkatkan pemahaman masyarakat terkait dengan informasi jenis sampah dan bagaimana mengelola sampah tersebut mulai dari rumah tangga.

4. Kegiatan ini juga menghasilkan beberapa masukan dan saran terakit dengan modul pembelajaran berbasis lingkungan - pilah sampah dari rumah.

5. Kegiatan pelatihan ini memberikan satu pengalaman dan pengetahuan baru tentang informasi pengolahan sampah rumah tangga dan komunitas yang secara umum sudah diketahui namun secara khusus belum direalisasi dalam tindakan baik individu, rumah tangga maupun komunitas.
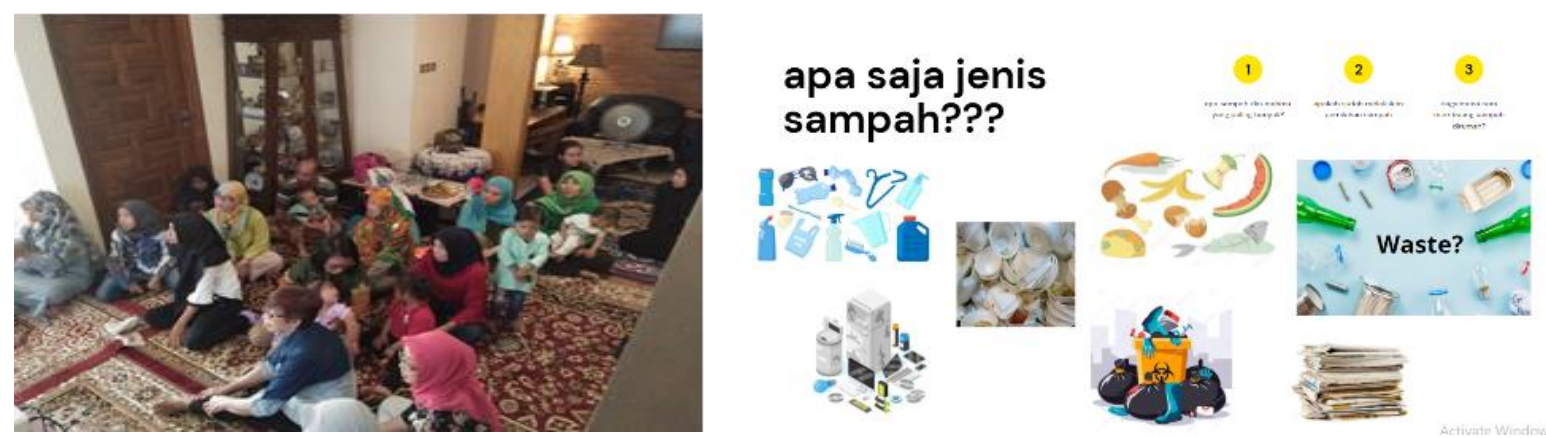

Gambar 8. Pelaksanaan Kegiatan Pembedayaan Masyarakat Dalam Mengelola Sampah Berbasis Komunitas

\subsection{Capaian Hasil Tahap V}

Pada tahap V, evaluasi kegiatan selama proses pelatihan menghasilkan satu kesimpulan bahwa terdapat beberapa hal terutama adanya konsep yang telah disempurnakan dalam kegiatan ini karena telah mendapat masukan perbaikan baik berupa saran maupun kritik dari peserta pelatihan. Hasil evaluasi kegiatan juga menjelaskan bahwa kegiatan yang telah dilaksanakan berjalan dengan sangat baik dan sesuai harapan. Hal tersebut terlihat dari jawaban yang diberikan oleh masing masing peserta pelatihan pada instrument pre test dan post test. 


\subsection{Capaian Hasil Tahap IV}

Pada tahap VI, penyelesaian laporan kegiatan pengabdian masyarakat merupakan capaian utama dan kemudian diserahkan kepada pihak fakultas sebagai bentuk pertanggung jawaban tim dalam melaksanakan kegiatan ini. Capaian hasil tahap IV juga berupa video pelaksanaan kegiatan pengabdian yang ditampilkan pada situs youtube berikut: https://www.youtube.com/channel/UCrrNBeaWIzYYSqXiF-NMj3g.

Secara umum, substansi dari capaian kegiatan berjalan dengan lancar dan berhasil. Keberhasilan ini tidak hanya diukur dari ketercapaian tujuan pelatihan namun juga interaksi dari peserta dan pemateri, banyaknya masukan sebagai tambahan data untuk pembuatan modul pembelajaran dan kepuasan para peserta yang mengikuti kegiatan tersebut. Tanggapan peserta secara umum sangat positif dan memiliki harapan bahwa kegiatan ini tidak hanya berlangsung satu kali namun bisa menjadi serangkaian kegiatan yang dapat memberikan masukan serta imput bagi pengembangan model pengelolaan sampah berbasis komunitas dengan harapan akan ada pembangunan Bank Sampah di Desa sebagai bentuk implementasi kegiatan tersebut. Peserta dapat merasakan manfaat setelah mengikuti pemberdayaan. Terdapat manfaat yang dirasakan oleh peserta sosialisasi antara lain:

1. Memperluas wawasan dan pemahaman peserta mengenai sampah, jenis, dan pengelolaannya di rumah tangga.

2. Membantu peserta dalam memiliki keterampilan untuk dapat mengelola sampah dan membangun inisiatif komunitas untuk mengembangkannya menjadi bank sampah/

3. Meningkatkan kesadaran masyarakat untuk mengelola sampah sejak dari rumah tangga.

Capaian hasil pada tahap keempat yang kedua yaitu menghasilkan sebuah modul pembelajaran dengan fokus kajian pada pengelolaan sampah berbasis komunitas yang akan diserahkan kepada mitra (Desa Bojong Jengkol dan Ketua RW Kampung Bengle). Tujuan penyerahan modul tersebut agar mitra memiliki gambaran lengkap mengenai pentingnya pembelajaran berbasis lingkungan dengan harapan agar dapat diimplementasikan sebagai suatu kegiatan dan pembangunan model pengelolaan sampah berbasis komunitas melalui Bank Sampah di Kampung Bengle.

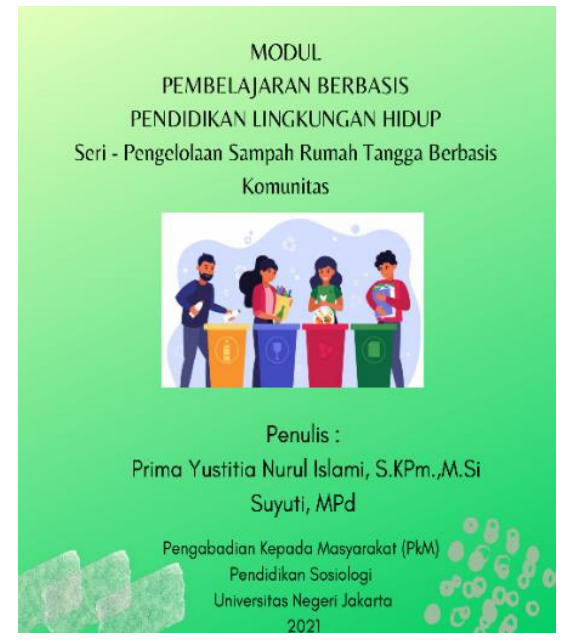

Gambar 9. Modul Pembelajaran Berbasis Pendidikan Lingkungan - Seri Pengelolaan Sampah Rumah Tangga Berbasis Komunitas

\subsection{Kendala yang dihadapi}

Pelaksanaan kegiatan pengabdian kepada masyarakat yang dilakukan di Kampung Bengle memiliki beberapa kendala baik yang bersifat teknis maupun non teknis. Kendala teknis salah satunya terkait dengan penentuan waktu pelaksanaan dan metode pelaksanaan sebab adanya aturan pembatasan sosial yang diterapkan oleh pemerintah sehingga pemberdayaan masyarakat dengan target 20 orang perempuan kemudian mengalami perubahan teknis pelaksanaan. Teknis pelaksanaan yang awalnya adalah full luring berubah menjadi tiga tahapan : 1) diskusi dengan 
pemerintah desa ; 2) presentasi dan diskusi dengan masyarakat; 3) pembagian booklet dan memberikan informasi link youtube kepada masyarakat. Tujuan kegiatan ini adalah agar informasi terkait dengan pengelolaan sampah berbasis komunitas tetap dapt diterima oleh masyarakat secara lengkap dan menyeluruh serta dapat diterima oleh semua pihak.

\subsection{Evaluasi kegiatan}

Kegiatan evaluasi pemberdayaan masyarakat yang dilakukan di Kampung Bengle menggunakan instrumen pre test dan post test untuk melihat perubahan pengetahuan masyarakat sebelum dan sesudah kegiatan ini dilaksanakan. Instrumen pre test dilakukan untuk mengetahui beberapa pengetahuan dan tindakan yang dilakukan oleh masyarakat desa terkait dengan pengelolaan sampah antara lain:

a. Perilaku memilah sampah

b. Pengetahuan jenis sampah

c. Tindakan mengelola sampah

Selain itu, terdapat pertanyaan terkait tindakan pengelolaan sampah yang dilakukan selama ini apakah sudah melakukan pemilahan, hanya mengumpulkan atau bahkan membuang di sembarang lokasi saja. Pertanyaan terakhir yang diberikan kepada peserta pelatihan adalah terkait informasi Bank Sampah apakah mengetahui dan sudah ada atau belum. Berikut penjelasan masing masing indikator hasil evaluasi pre test dari setiap kelompok pertanyaan, antara lain sebagai berikut:

\section{Pre Test 1 - Pengetahuan Pengelolaan Sampah Rumah Tangga}

Hasil pre test terkait dengan pengelolaan sampah rumah tangga menunjukkan bahwa 85\% masyarakat yang mengikuti kegiatan pemberdayaan belum melakukan pemilahan sampah rumah tangga dan sebanyak 3\% masyarakat sudah melakukan pemilahan sampah awal saja yaitu memisahkan sampah organik dan anorganik. Masyarakat yang memisahkan sampah bertujuan untuk menggunakan sampah organik sebagai pupuk sedangkan sampah anorganik ditumpuk atau dibakar. Hasil pre test terkait dengan pengetahuan jenis sampah menunjukkan bahwa sebanyak 55\% masyarakat sudah mengetahui jenis sampah rumah tangga (Gambar 10).

\section{Pengetahuan Pengelolaan Sampah Rumah Tangga}

20

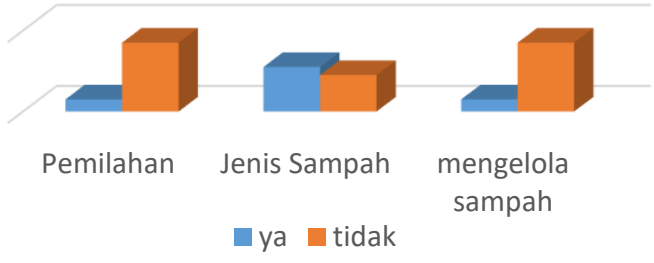

Gambar 10. Pengetahuan Tentang Pengeloalan Sampah Rumah Tangga

\section{Pre Test 2 - Model Pengelolaan Sampah Rumah Tangga}

Hasil pre test selanjutnya tentang model pengelolaan sampah rumah tangga yang dilakukan oleh peserta kegiatan pemberdayaan menunjukkan bahwa sebanyak 15\% masyarakat sudah melakukan pemilahan sampah namun belum teratur, sebagian masyarakat yang sudah melakukan pemilahan juga mengelola sampahnya dengan pola dikumpulkan kemudian dibakar maupun dibuang. Sebanyak 45\% masyarakat menyatakan bahwa melakukan pengeloalan sampah dengan mengumpulkan sampah didepan rumah atau lokasi pembuangan sampah sementara di kampung. Dan sebanyak 55\% masyarakat melakukan pola pengelolaan sampah rumah tangga dengan membuang sampah di sungai maupun ditempat lain (tidak di tempat pembuangan sampah sementara) (Gambar 11). 


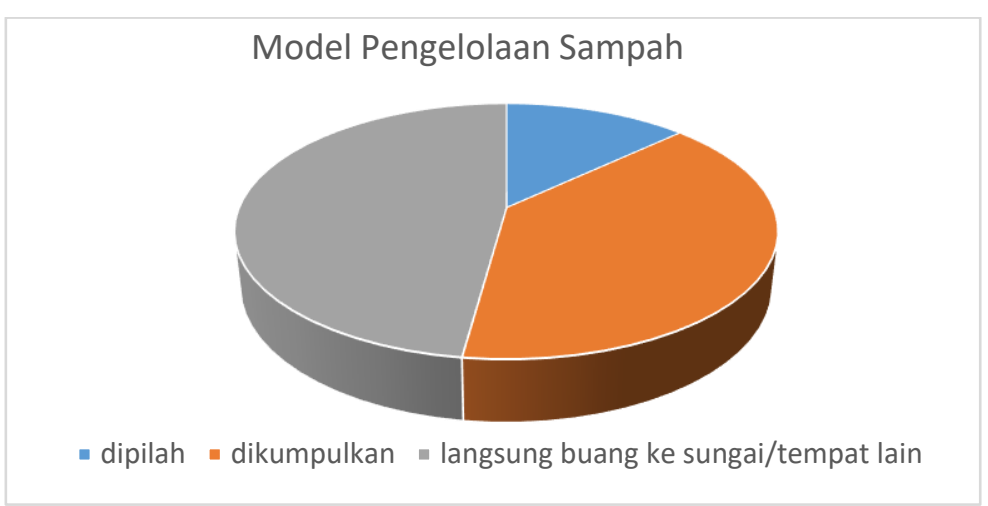

Gambar 11. Model Pengelolaan Sampah Rumah Tangga Di Kampung Bengle

\section{Pre Test 3 - Informasi Bank Sampah}

Hasil pre test ketiga terkait dengan informasi Bank Sampah menunjukkan bahwa sebagian besar dari peserta pelatihan tidak mengetahui tentang bank sampah maupun fungsi dari bank sampah. Selain itu informasi keberadaan bank sampah di desa pun belum pernah diketahui peserta pelatihan (Gambar 12).

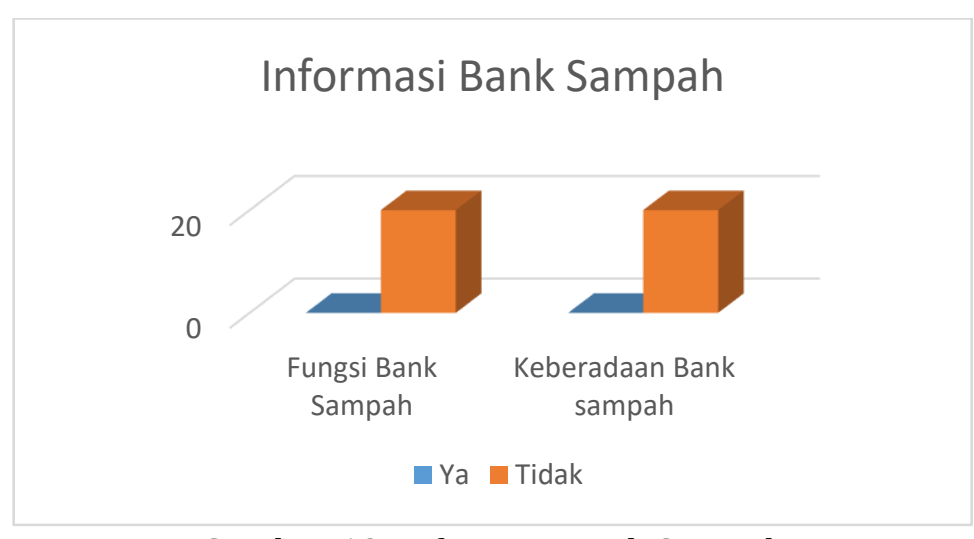

Gambar 12. Informasi Bank Sampah

\section{Kesimpulan Pre Test}

Hasil pre test terkait informasi awal tentang pengelolaan sampah yang sudah dilakukan, jenis sampah dan informasi terkait bank sampah menunjukkan bahwa sebagian besar masyarakat masih melakukan pola pengelolaan sampah awal dengan metode langsung buang ke sungai atau tempat lainnya. Selain itu juga masyarakat belum mengetahui informasi terkait bank sampah yang ada di desa tersebut. Berdasarkan hal tersebut, pasca kegiatan pelatihan dilakukan maka peserta diberikan kembali beberapa pertanyaan terutama terkait dengan aspek peningkatan pengetahuan dan peningkatan informasi.

Hasil post terkait dengan kedua aspek tersebut adalah sebagai berikut :

\section{Post Test}

Instrumen post tes dilakukan untuk mengetahui pasca diberikan informasi dan pelatihan maka aspek pengetahuan masyarakat mana saja yang mengalami peningkatan. Instrumen post test yang dilakukan meliputi

a. Perubahan pengetahuan

b. Peningkatan Informasi

\section{Post Test 1 - Perubahan Pengetahuan}

Hasil post test setelah dilakukan pelatihan kepada masyarakat kampung bengle menunjukakn bahwa terdapat peningkatan pengetahuan terkait dengan pola pengelolaan sampah 
mulai dari tahapan pemilahan, mengetahui manfaat dari pemilahan sampah, mengetahui jenis sampah, dan tata cara mengelola sampah yang baik sejak dari rumah tangga (Gambar 13).

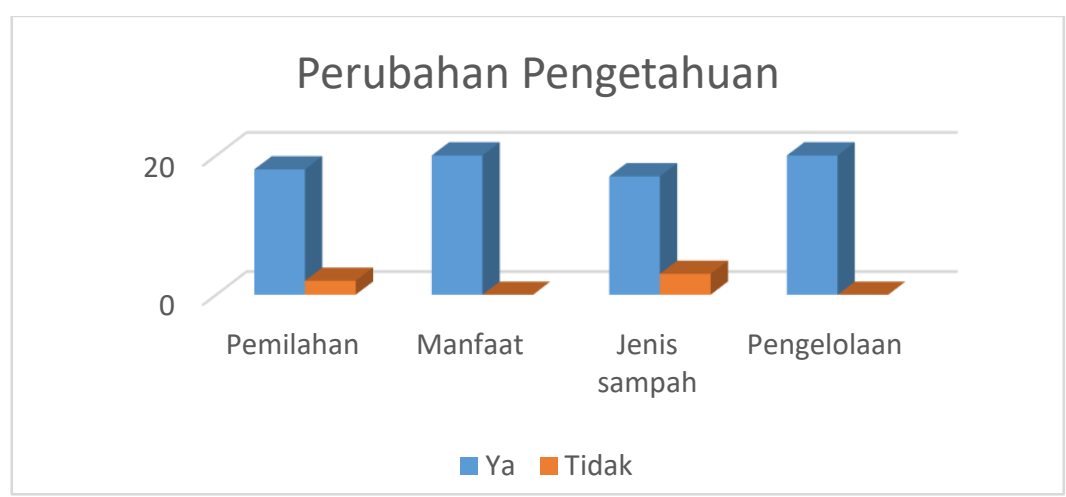

Gambar 13. Perubahan pengetahuan pasca pelatihan pengelolaan sampah rumah tangga

\section{Post Test 2 - Peningkatan Informasi}

Hasil post test pada aspek kedua yaitu peningkatan informasi menunjukkan bahwa sebagian besar masyarakat mendapat informasi baru terkait dengan pengelolaan sampah, jenis sampah, informasi terkait bank sampah maupun model pengeloalan yang dilakukan melalui bank sampah. Walaupun sebagian kecil dari peserta juga masih belum memahami materi sehingga informasi belum dapat diterima dengan baik (Gambar 14).

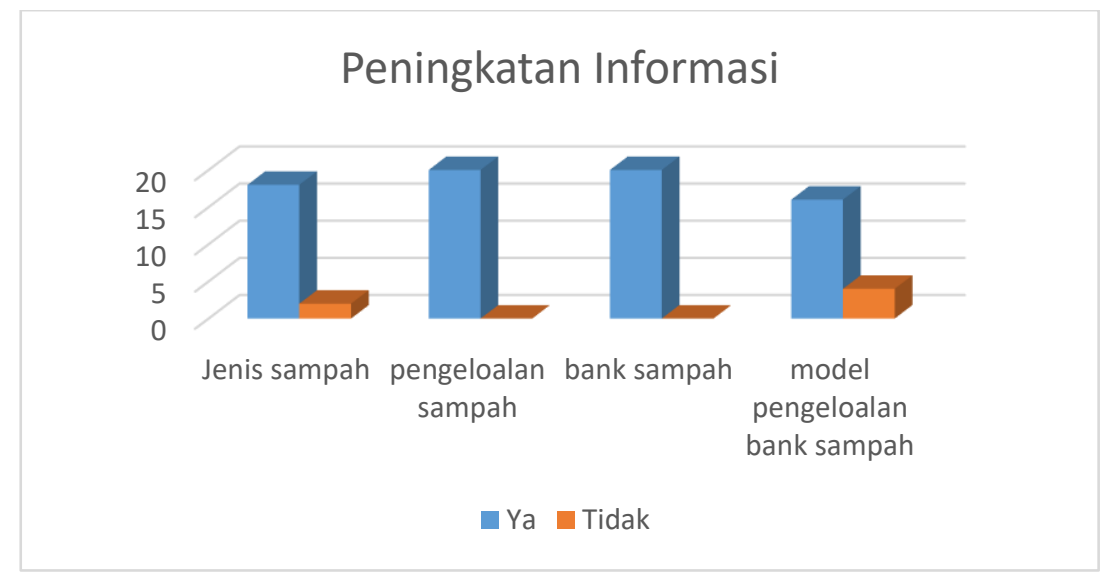

Gambar 14. Peningkatan Informasi pasca pelatihan pengelolaan sampah rumah tangga

\section{Kesimpulan Post Test}

Hasil post test terkait dengan pengeloalan sampah pasca dilakukan pelatihan menunjukkan bahwa lebih dari 50\% peserta pelatihan memiliki pengetahuan baru (meningkat pengetahuannnya) terkait dengan pengelolaan sampah, informasi jenis sampah, bagimana mengelola sampah di level komunitas dan beberapa informasi yang disampaikan saat pelatihan pengelolaan sampah di Kampung Bengle.

\section{KESIMPULAN}

Kegiatan pemberdayaan masyarakat dalam bentuk pelatihan pengeloalan sampah rumah tangga berbasis komunitas bertujuan untuk membangun pemahaman dan persamaan pandangan baik masyarakat dan pemerintah tentang model pengelolaan sampah yang baik; Kegiatan pelatihan dapat meningkatkan pengetahuan masyarakat dengan harapan dapat mengembangkan kemampuan masyarakat dalam melakukan pemilahan sampah sebelum dibuang atau dikumpulkan. Youtube sebagai media sosial memberikan pengaruh yang besar terutama dalam menjangkau khalayak yang lebih luas. Tujuan utama dari peningkatan kesadaran masyarakat 
dapat dilakukan terus menerus melalui media youtube. Hasil kegiatan cukup baik dilihat dari indikator peningkatan pengetahuan, dari aspek media youtube tidak dilakukan evaluasi terkait seberapa besar masyarakat yang menyaksikan youtube, namun secara umum informasi tersebut dapat diterima dengan baik oleh masyarakat. Hasil pre test terkait informasi awal tentang pengelolaan sampah yang sudah dilakukan, jenis sampah dan informasi terkait bank sampah menunjukkan bahwa sebagian besar masyarakat masih melakukan pola pengelolaan sampah awal dengan metode langsung buang ke sungai atau tempat lainnya dan belum mengetahui informasi terkait bank sampah yang ada di desa tersebut. Berdasarkan hal tersebut, pasca kegiatan pelatihan dilakukan maka peserta diberikan kembali beberapa pertanyaan terutama terkait dengan aspek peningkatan pengetahuan dan peningkatan informasi. Hasil post test terkait dengan pengeloalan sampah pasca dilakukan pelatihan menunjukkan bahwa lebih dari $50 \%$ peserta pelatihan memiliki pengetahuan baru (meningkat pengetahuannnya) terkait dengan pengelolaan sampah, informasi jenis sampah, bagimana mengelola sampah di level komunitas dan beberapa informasi yang disampaikan saat pelatihan pengelolaan sampah di Kampung Bengle.

\section{UCAPAN TERIMA KASIH}

Penulis mengucapkan terima kasih kepada Pemerintah Desa Bojong Jengkol, masyarakat Kampung Bengle, Desa Bojong Jengkol, Kelurahan Cihideung Udik, Kecamatan Ciampea, Kabupaten Bogor Jawa Barat yang telah memberikan dukungan dan keterlibatan secara aktif dalam kegiatan ini.

\section{DAFTAR PUSTAKA}

Listiyandini, R., Aisyah, N., Robby, P. A., \& Kurniawan, D. (2018). Pemanfaatan Bank Sampah untuk Mengelola Limbah Rumah Tangga di Desa Ciharashas Kelurahan Mulyaharja Kota Bogor. PROMOTOR Jurnal Mahasiswa Kesehatan Masyarakat, 1(2), 116-123.

Mujiburrahmad, \& Firmansyah. (2014). Hubungan Faktor Individu Dan Lingkungan Sosial Dengan Partisipasi Masyarakat Dalam Pengelolaan Sampah Rumah Tangga (Kasus Kampung Sengked, RT 03/RW 03 Desa Babakan Kecamatan Dramaga, Kabupaten Bogor). Jurnal Agrisep, 15(1), 47-66. https://doi.org/10.24815/agrisep.v15i1.2092

Rainiyati, R., Riduan, A., Zulkarnain, Z., Eliyanti, E., \& Heraningsih, S. F. (2019). Pemanfaatan Sampah Rumah Tangga Menjadi Beberapa Jenis Pupuk Cair MOL (Mikro Organisme Lokal) di Desa Pudak Kecamatan Kumpeh Ulu Kabupaten Muara Jambi. Jurnal Pengabdian Pada Masyarakat, 4(4), 555-562. https://doi.org/10.30653/002.201944.227

Utami, B. D., Indrasti, N. S., \& Dharmawan, A. H. (2008). Pengelolaan Sampah Rumahtangga Berbasis Komunitas: Teladan dari Dua Komunitas di Sleman dan Jakarta Selatan. Sodality: Jurnal Sosiologi Pedesaan, 2(1), 49-68. https://doi.org/10.22500/sodality.v2i1.5893 